\title{
要支援高齢者における活動強度に着目した 身体活動量と歩行能力との関連
}

\author{
Relationship between the Physical Activity and Walking Ability of the Elderly \\ Requiring Minimal Assistance: Focus on Intensity of Daily Activity
}

\begin{abstract}
相馬 夏月 ${ }^{1)}$ 横川 正美 ${ }^{2)}$ 内山 圭太 ${ }^{1)}$ 間所 祥子 ${ }^{2)}$ 三秋 泰一 ${ }^{2)}$
KAZUKi SOUMA, RPT ${ }^{1)}$, MASAMI YOKOGAWA, RPT, PhD ${ }^{2)}$, KeITA UCHIYAMA, RPT, $\mathrm{PhD}^{1)}$, SACHIKO MADOKORO, RPT, $\mathrm{PhD}^{2)}$, HIROICHI MIAKI, RPT, $\mathrm{PhD}^{2)}$

1) Department of Rehabilitation, Japanese Red Cross Kanazawa Hospital: 2-251 Minma, Kanazawa-shi, Ishikawa 921-8162, Japan TEL+81 76-242-8131 E-mail: k.souma0730@gmail.com

${ }^{2)}$ Faculty of Health Sciences, Institute of Medical, Pharmaceutical and Health Science, Kanazawa University
\end{abstract}

Rigakuryoho Kagaku 36(4): 601-606, 2021. Submitted Feb. 22, 2021. Accepted Apr. 15, 2021.

\begin{abstract}
Purpose] To measure the physical activity of the elderly requiring minimal assistance, focusing on activity intensity, and to examine its relationship with the 10-m walking time (10-mWT). [Participants and Methods] The daily step counts, and time spent in physical activity (light [LPA] and moderate-to-vigorous physical activity [MVPA], 1.6-2.9 and $\geq 3.0$ metabolic equivalents, respectively) of 28 elderly individuals (9 males, 19 females) requiring minimal assistance were measured. Their 10-mWT, grip strength, Timed Up \& Go Test (TUG), Functional Reach Test, Geriatric Depression Scale-15 (GDS-15), and life space assessments were also evaluated. [Results] For the 20 participants with successful measurements of physical activity, the times spent in LPA and MVPA were 306 \pm 114 minutes/day and $16.6 \pm 20.8$ minutes/day, respectively. Multiple-regression analysis demonstrated that TUG and GDS-15 scores, MVPA, and grip strength were associated with the 10-mWT. [Conclusion] MVPA of the elderly requiring minimal assistance was lower than previously reported and may be associated with the 10-mWT.
\end{abstract}

Key words: elderly people requiring minimal assistance, activity intensity, $10 \mathrm{~m}$ walking time

要旨：〔目的〕要支援高齢者の身体活動量（PA）を活動強度に着目して測定し，歩行能力との関連を検討した。〔対 象と方法了要支援高齢者 28 名（男性 9 名，女性 19 名）の活動量計を用いて PA を測定した. PA は $1.6 〜 2.9$ METs を light-intensity physical activity（LPA），3.0 METs 以上を moderate to vigorous physical activity（MVPA）の時間と した。加えて，運動・心理機能および生活活動度を測定した。〔結果〕PA を測定できた 20 名の LPA $306 \pm 114$ 分 ／日，MVPA $16.6 \pm 20.8$ 分／日であった。重回帰分析では $10 \mathrm{~m}$ 歩行時間に関連する要因として LPAは選択されず、 MVPA が選択された。〔結語〕要支援高齢者の身体活動量の増進を考えるうえで, 特にMVPAに着目する重要性が 示唆された.

キーワード : 要支援高齢者, 活動強度, $10 \mathrm{~m}$ 歩行時間

\footnotetext{
1) 金沢赤十字病院 リハビリテーション科部：石川県金沢市三馬2-251（テ921-8162）TEL 076-242-8131

2) 金沢大学 医薬保健研究域 保健学系

受付日 2021 年 2 月 22 日 受理日 2021 年 4 月 15 日
} 


\section{I. はじめに}

活発な身体活動は，高齢者の健康増進と密接な関わり があるとされている1)，身体活動量の評価指標には歩数， 活動強度, 消費カロリー等があり ${ }^{2)}$, 測定の簡便さから 歩数が多く用いられている. 近年は歩数だけでなく, 活 動強度に着目することの重要性が示唆されており, Adachi ら 3) は, 中等度強度以上の身体活動が歩行能力 と関連すると報告している。

活動強度に基づいた身体活動の段階付けは，主に metabolic equivalents（以下, METs) が用いられてい る4)。また，活動強度に関する研究報告では，1.6〜2.9 METs の身体活動を light-intensity physical activity（以下 LPA), 3.0 METs 以上の身体活動を moderate to vigorous physical activity（以下，MVPA）と定義されることが多 い5,6). 両者とも様々な健康指標との関連が報告されて いるが, とりわけMVPA は歩行能力をはじめとする運 動機能との関連が示されており3,7), 世界保健機関 （WHO）の身体活動に関するガイドラインのなかでも MVPAの増進が推奨されている ${ }^{8)}$.

本邦の要支援・要介護高齢者は, 2020 年 5 月時点で 668.6 万人に上る ${ }^{9)}$. 介護保険制度における要介護認 定 ${ }^{10)}$ により, 要支援 1 もしくは要支援 2 と認定された 高齢者（以下，要支援高齢者）が要介護状態へ移行する のを防ぐためには，身体機能の維持・向上を図ることが 重要である.MVPA が歩行能力の維持と密接に関連す ることから ${ }^{3,7)}$, 要支援高齢者においても日常生活のな かでの身体活動量ひいては活動強度に留意することが望 ましいと考えられる，先行文献では，要支援・要介護高 齢者の身体活動量は, 健常高齢者と比較して低下するこ とが報告されている11,12)。しかし，これらの調査では 身体活動量を歩数によって評価しており，要支援高齢者 を対象に活動強度に着目した身体活動量の調査はなされ ていない, そのため, 活動強度を加味した身体活動増進 への取り組みを支援しようとする時, LPA P MVPAに 相当する身体活動を要支援・要介護高齢者がどの程度 行っているのかは不明瞭な状況である.

要支援高齢者は運動機能の低下や，それに伴う社会参 加への制約を生じる場合があり，特にMVPA と同等の 身体活動を日常生活のなかで行う機会が減少していると 予想される。一方, LPA は MVPA と比較して強度も低 いことから，要支援高齢者にも取り組みやすい身体活動 である。この LPA と歩行能力に関連が示されれば，要 支援高齢者の身体活動を増進する方策の一つとなると考 えられる。

よって, 本研究の目的は, 要支援高齢者の身体活動量 を活動強度に着目して調査することおよび活動強度と歩 行能力との関連を検討することとした.

\section{II. 対象と方法}

\section{1. 対象}

通所リハビリテーションを利用する要支援高齢者 28 名を対象とした。対象者の年齢は $75.1 \pm 9.0$ 歳（平均 \pm 標準偏差), 男性 9 名, 女性 19 名であった。取り込 み基準として, 歩行補助具や装具の有無は問わず，歩行 を主な移動手段としている者とした。除外基準は，本研 究の内容拈よび活動量計の装着方法について, 十分な理 解を得ることが困難な可能性のある者 (Mini-Mental State Examinationの得点 24 点未満）とした。すべての 対象者に, 本研究の趣旨と内容を口頭および文書で十分 に説明し書面にて同意を得た。本研究は，金沢大学医学 倫理審査委員会の承認を得て行った（承認番号：8842).

\section{2. 方法}

身体活動量の測定は 2019 年 8 月〜2019 年 11 月の期 間に実施した。季節による身体活動量への影響 13) を考 慮して, 測定時期を 8〜11月とした。身体活動量の測定 には, 活動量計 (HJA-750C Active style pro, オムロン 社製）を使用した。本機器は 3 軸加速度センサーにより 加速度を検出し, 独自のアルゴリズムから, 歩数の検出 や身体活動の強度を算出している13)。本機器により算 出された身体活動の強度は, 熱量測定法による実測值と 高い相関を示すことが確認されている14)。活動量計の 装着部位は腰部とし, 起床時から就寝時まで入浴時を除 いて常に装着するように依頼した。活動量計の装着期間 は7 日間以上とした。活動量計の測定単位時間（epoch length）は，先行研究と同様に 60 秒区分とした ${ }^{5)}$. 本 機器の活動強度は 1.0 MET から 0.1 METs ごとに検出さ れる。検出されたデー夕を $1.0 〜 1.9 \mathrm{METs}, \quad 2.0 \sim 2.9$ METs, 3.0 3.9 METs, $4.0 \sim 4.9$ METs, 5.0 5.9 METs, $6.0 \mathrm{METs}$ 以上に分けて, それぞれの活動強度で活動し た時間を集計した。ささらに1.6〜2.9 METs の身体活動を $\mathrm{LPA}^{6}$ ，3.0 METs 以上の身体活動を $\mathrm{MVPA}^{3,7)}$ とし，そ れぞれの活動時間を集計した。歩数と上記の活動時間の 1 日あたりの平均值を算出し測定值とした.

運動機能評価として握力, Timed Up and Go Test（以 下, TUG), Functional Reach Test (以下, FRT), $10 \mathrm{~m}$ 歩行時間を測定した。握力は，アナログ握力計（TTM スメドレー握力計 YO- II，ツツミ社製）を使用し，立 位にて測定した。TUGは，椅子座位を開始姿勢として， $3 \mathrm{~m}$ の直線路を往復し, 再び椅子座位に戻るまでの時間 を測定した，FRTは，静止立位から上肢をできるだけ 前方にリーチし, その到達距離を測定した. $10 \mathrm{~m}$ 歩行 時間は, $14 \mathrm{~m}$ の直線路のうち両端から $2 \mathrm{~m}$ ずつを予備 路として，最大努力歩行にて実施した。 TUG および 10 $\mathrm{m}$ 歩行時間の測定時は, 歩行補助具や装具を使用して 
表 1 対象者の基本属性

\begin{tabular}{llcc}
\hline & & $\begin{array}{c}\text { 歩数測定できた対象者 } \\
(\mathrm{n}=20)\end{array}$ & $\begin{array}{c}\text { 歩数測定できなかった対象者 } \\
(\mathrm{n}=8)\end{array}$ \\
\hline 年齢 (歳) & & $75.4 \pm 9.2$ & $74.0 \pm 10.8$ \\
\hline 性別 & 男性 & $7(35.0)$ & $2(25.0)$ \\
& 女性 & $13(65.0)$ & $6(75.0)$ \\
\hline 介護区分 & 要支援 1 & $5(25.0)$ & $3(37.5)$ \\
& 要支援 2 & $15(75.0)$ & $5(62.5)$ \\
\hline 主傷病 & 骨・関節疾患 & $13(65.0)$ & $2(25.0)$ \\
& 脳血管疾患 & $4(20.0)$ & $5(62.5)$ \\
& 内部疾患 & $1(5.0)$ & $0(0)$ \\
& 神経疾患 & $2(10.0)$ & $1(12.5)$ \\
\hline 歩行補助具 & なし (独歩) & $9(45.0)$ & $2(25.0)$ \\
& 杖 & $8(40.0)$ & $5(62.5)$ \\
& シルバーカー & $3(15.0)$ & $1(12.5)$ \\
\hline 装具 & なし (独歩) & $18(90.0)$ & $7(87.5)$ \\
& 短下肢装具 & $2(10.0)$ & $1(12.5)$ \\
\hline
\end{tabular}

平均值 \pm 標準偏差または該当人数 $(\%)$.

いる場合はそれらを使用し測定した。これらの運動機能 評価は，それぞれ 2 回ずつ測定し，より成績の良い数值 を結果として採用した。

心理機能検査として, Geriatric Depression Scale-15 (以下, GDS-15), 生活活動度評価として, Life Space Assessment（以下，LSA）を実施した。 GDS-15 は，高 齢者の抑うつ状態を評価するスクリーニング検査として 世界的に使用されている評価スケールである ${ }^{15)}$. LSA は，個人の生活空間の広がりを評価する指標である ${ }^{16) . ~}$ 生活空間の範囲を, 寝室から町外までの 5 つの範囲に区 分して, 過去 4 週間の生活範囲とその頻度㧍よび自立度 から最高 120 点で点数化している ${ }^{15)}$. GDS-15 および LSA は，同一の検者が口頭にて質問し測定した.

活動量計により測定した身体活動量の解析において, 歩数が著しく少ない対象者が存在した。これらの対象者 の歩数より, 1 日当たりの歩数が 300 歩以上の者を歩数 測定できた対象者とし，300 歩未満の者を歩数測定でき なかった対象者とした。 2 群の各評価項目の值を比較す るため，対応のない $\mathrm{t}$ 検定を実施した

その後, 歩数測定できた対象者について, $10 \mathrm{~m}$ 歩行 時間を従属変数, 年齢, LPA, MVPA, 握力, TUG, FRT, GDS-15, LSA を独立変数とし, 変数増減法で久 テップワイズ法による重回帰分析を行った。独立変数間 の共線性の診断を行った後, 各因子の標準化偏回帰係数 （ß）を求め, 歩行速度との関連の強さを検討した，有意 水準は $5 \%$ とした，全ての統計解析には SPSS ver.23 （IBM 社製）を使用した。
表 2 歩数測定の可否による各評価項目の比較

\begin{tabular}{lcc}
\hline & $\begin{array}{c}\text { 歩数測定できた } \\
\text { 対象者 }(\mathrm{n}=20)\end{array}$ & $\begin{array}{c}\text { 歩数測定できな } \\
\text { かった対象者 } \\
(\mathrm{n}=8)\end{array}$ \\
\hline 年齢 (歳) & $75.5 \pm 9.2$ & $74.0 \pm 10.8$ \\
歩数 (歩 $/$ 日) & $2316 \pm 1899^{*}$ & $170 \pm 82^{*}$ \\
LPA (分 $/$ 日) & $306.0 \pm 114.0$ & $267.0 \pm 122.0$ \\
MVPA (分 $/$ 日) & $16.6 \pm 20.8^{*}$ & $5.5 \pm 4.7^{*}$ \\
握力 (kg) & $22.0 \pm 9.5$ & $20.7 \pm 8.7$ \\
TUG (秒) & $11.0 \pm 2.8^{*}$ & $16.0 \pm 6.5^{*}$ \\
FRT (cm) & $26.4 \pm 6.6^{*}$ & $19.5 \pm 3.9^{*}$ \\
$10 \mathrm{~m}$ 歩行時間 (秒) & $9.7 \pm 2.6^{*}$ & $14.3 \pm 6.4^{*}$ \\
GDS-15 (点) & $4.2 \pm 2.8$ & $4.0 \pm 3.2$ \\
LSA (点) & $56.2 \pm 17.4^{*}$ & $38.9 \pm 12.5^{*}$ \\
\hline
\end{tabular}

平均值 \pm 標準偏差. LPA : light-intensity physical activity, MVPA : moderate to vigorous physical activity, TUG : Timed Up and Go Test, FRT : Functional Reach Test, GDS-15 : Geriatric Depression Scale-15, LSA : Life Space Assessment. *: $\mathrm{p}<0.05$

\section{III. 結 果}

対象者の基本属性を表 1 に示した，歩数測定できた対 象者は 20 名, 歩数測定できなかった対象者は 8 名であっ た. 歩数測定できなかった対象者は, 歩数測定できた対 象者と比較して，MVPA，FRT， LSAにて有意に低值 を認め, TUG, $10 \mathrm{~m}$ 歩行時間にて有意に高值を認めた (表2). 
表 3 要支援高齢者の身体活動量

\begin{tabular}{|c|c|c|c|}
\hline & 全体（n=20） & 男性（n=7） & 女性（n=13） \\
\hline 歩数（歩／日） & $2316 \pm 1899$ & $2664 \pm 2228$ & $2128 \pm 1766$ \\
\hline $1.0 \sim 1.9 \mathrm{METs}$ (分 $/$ 日） & $600.0 \pm 179.0$ & $505.0 \pm 122.0$ & $651.0 \pm 187.0$ \\
\hline $2.0 \sim 2.9 \mathrm{METs}$ (分 $/$ 日） & $148.0 \pm 71.0$ & $114.0 \pm 56.0$ & $167.0 \pm 72.0$ \\
\hline 3.0 3.9 METs（分／日） & $15.2 \pm 19.0$ & $13.1 \pm 12.0$ & $16.3 \pm 22.3$ \\
\hline 4.0 4.9 METs（分／日） & $1.1 \pm 1.6$ & $0.6 \pm 0.5$ & $1.3 \pm 2.1$ \\
\hline 5.0 5.9 METs（分／日） & $0.2 \pm 0.4$ & $0.1 \pm 0.1$ & $0.3 \pm 0.5$ \\
\hline 6.0 METs～（分／日） & $0.1 \pm 0.1$ & $0.0 \pm 0.0$ & $0.1 \pm 0.2$ \\
\hline LPA（1.6 2.9 METs）（分／日） & $306.0 \pm 114.0$ & $226.0 \pm 78.0$ & $349.0 \pm 109.0$ \\
\hline MVPA（3.0 METs～）（分／日） & $16.6 \pm 20.8$ & $13.8 \pm 11.7$ & $18.1 \pm 24.6$ \\
\hline
\end{tabular}

平均值 \pm 標準偏差. LPA : light-intensity physical activity, MVPA : moderate to vigorous physical activity.

歩数測定できた対象者 20 名について, 身体活動量の 概要を表 3 に示した。 1 日当たりの身体活動量は, 歩数 は男性 $2664 \pm 2228$ 歩, 女性 $2128 \pm 1766$ 歩, LPA は 男性 $226.0 \pm 78.0$ 分, 女性 $349.0 \pm 109.0$ 分, MVPA は男性 $13.8 \pm 11.7$ 分, 女性 $18.1 \pm 24.6$ 分（平均 \pm 標 準偏差）であった。

$10 \mathrm{~m}$ 歩行時間を従属変数とした重回帰分析では, TUG $(\beta=0.791), \operatorname{GDS}-15(\beta=0.366), \operatorname{MVPA}(\beta=$ $0.165)$, 握力 $(\beta=0.142)$ が選択された。調整済み $\mathrm{R}^{2}$ は 0.959 となった（表 4).

\section{IV. 考 察}

本研究は, 要支援高齢者の身体活動量を調査した，解 析結果から, 1 日の平均歩数が 300 歩未満の歩数が極端 に少ない者が存在した，本研究の対象者は，主な移動手 段を歩行としており，少なくとも通所リハビリテーショ ンの歩行練習に执いて 300 歩以上の歩行を行っている ことを確認しているが, 歩数測定できなかった対象者の 活動量計の測定結果に歩行練習の歩数は反映されていな かった. 活動量計もしくは歩数計による歩数の検出に関 して, 歩行速度の遅い者や脳卒中片麻瘦患者では, 過小 評価される可能性のあることが報告されている ${ }^{17)}$ 。本 研究の歩数測定できなかった対象者においても, 歩行能 力の有意な低下が認められた（表 2)。また, 本研究で 使用した活動量計は, 3 軸性加速度センサーによって検 知された加速度の強さと方向から歩行活動を認識するこ とで歩数を検出しており ${ }^{13)}$, 正常歩行から逸脱した歩 容や歩行補助具の使用が, 活動量計の適切な歩数検出に 影響を与えたとも考えられる。こうした状態の要支援高 齢者の身体活動量を把握することは, 介護予防の観点か らより一層重要であると考えられるが, 活動量計による 正確な歩数の評価が困難であり, 使用する器具や測定方 法について, 今後検討を要する.
表 4 重回帰分析の結果

\begin{tabular}{lc}
\hline \multicolumn{1}{c}{ 選択された独立変数 } & $\beta$ (標準化変数) \\
\hline TUG & 0.791 \\
GDS-15 & 0.366 \\
MVPA & 0.165 \\
握力 & 0.142 \\
\hline
\end{tabular}

従属変数：10 m 歩行時間. 独立変数：年齢, LPA, MVPA 握力, TUG, FRT, GDS-15, LSA. 調整済み $\mathrm{R}^{2}: 0.959$. TUG : Timed Up and Go Test, GDS-15 : Geriatric Depression Scale-15, MVPA : moderate to vigorous physical activity, LPA : light-intensity physical activity, FRT : Functional Reach Test, LSA : Life Space Assessment.

歩数測定できた対象者の身体活動量について考察す る. 要支援・要介護高齢者の歩数を調査した先行研究で は2000３000 歩/日程度であり 11,12), 本研究の結果も 先行研究と類似していた。平成 30 年国民健康・栄養調 查による 70 歳以上の地域高齢者の 1 日の平均歩数は, 男性 5053 歩, 女性 4317 歩とされる ${ }^{18)}$. よって, 本研 究の対象者の歩数は, 地域高齢者の歩数と比較すると低 下していると考えられる。

活動強度に着目すると, 地域高齢者を対象とした Izawa ら 5) の調査では, LPA は男性 $289.9 \pm 104.4$ 分 / 日, 女性 $384.8 \pm 108.2$ 分/日, MVPA は男性 $50.9 \pm$ 37.6 分/日, 女性 $48.1 \pm 27.3$ 分/日であった。 また, 天笠ら 6)の調查では, LPA は男性 $263.1 \pm 87.4$ 分 /日, 女性 $365.3 \pm 90.2$ 分/日, MVPA は男性 $43.6 \pm 30.1$ 分/日, 女性 $46.3 \pm 22.8$ 分/日であった。 これらの調 查結果と比較すると, 本研究対象者の MVPA は低值で あり, 要支援高齢者ではMVPA の低下を生じることが 示唆された。 この要因として, 歩行能力や筋力等の運動 機能と身体活動量の相関関係が示されており 5,11 , 要支 援高齢者の身体活動量の減少の一因に, 主傷病掞よび併 
存疾患に由来する運動機能の低下が考えられる．

その一方で，要支援高齢者を対象とした縦断的調査に て ADL 能力に変化がないにもかかわらず, 身体活動量 が低下することが報告されている ${ }^{19)}$ ，要支援高齢者の 身体活動量減少は, 運動機能の低下のみではなく, 社会 的背景など様々な要因が関与する20)と考えられる。環 境的な要因の一例に気象 ${ }^{19)}$ が挙げられ, 社会的背景 ${ }^{20)}$ の例として, 活動を共にする家族・友人の有無, 趣味の 有無等があるが, 本研究では対象者の社会的背景の項目 を調査していないため, この点について考察することは できず，今後検証していく必要がある。

$10 \mathrm{~m}$ 歩行時間を従属変数とした重回帰分析では, TUG, GDS-15, MVPA，握力が選択された。これらの 項目は，いずれも歩行速度との関連が報告されてお り 3,21-23), 本研究の対象者においても歩行能力との関連 を示したと考えられる。

本研究の重回帰分析で選択された MVPA は，骨格筋 量の維持 24) や脳血流量の増大 25$)$ など運動機能との関連 が示されている. Adachi ら 3,7)の地域高齢者を対象とし た研究において, 歩行能力に関連する要因として MVPA が選択されており，高齢者の運動機能維持にお けるMVPAの重要性を述べている。要支援高齢者を対 象とした本研究においても, 同様の結果となった。運動 機能の低下や社会参加への制約を有する要支援高齢者が 自身でMVPAを増やすことは容易ではないと考えられ， 通所リハビリテーションや介護予防事業にて, MVPA を含む運動介入を取り入れ, 強度の高い身体活動の機会 を提供することが必要だろう。要支援高齢者の健康状態 や背景因子は各個人によって多様であり, 一律の方法で 運動介入を行うと不都合が生じる可能性もある。本研究 で対象とした通所リハビリテーション施設では, 理学療 法士が利用者個別の運動プログラムを作成している。個 別の運動プログラムにおいて各個人の状況を考慮し, MVPA 程度の運動強度を組み込むことが考えられる。

本研究の重回帰分析では, TUG $(\beta=0.791)$, GDS$15(\beta=0.366)$ も歩行能力に関連する要因として選択さ れた。両者とも標準化係数は MVPA $(\beta=0.165)$ より 大きく, 歩行能力への影響が大きい要因と考えられる. そのため身体活動量のみでなく，運動機能や心理面への アプローチも考慮する必要がある。

LPA は, 死亡率の低下 26) や, 循環器系疾患の予防 27) に関するメリットが報告されている。ゆっくりとした体 操や家事動作等 28), LPA 程度の身体活動は，要支援高 齢者にとって自宅内でも安全に取り組みやすい活動であ り，10 m 歩行時間を従属変数とした重回帰分析で LPA が選択されることを期待したが, 今回は選択されなかっ た.

本研究の限界として, 対象者に顕著な跛行や歩行速度 の低下がある場合, 活動量計による歩数の検出は正確性
が不十分であること, 対象者数が少ないこと, 本研究は 横断研究であり要因間の因果関係を示すものではないこ とが挙げられる. 要支援高齢者の歩行能力に活動強度が 与える影響を明らかにするため,さらなる縦断的調査が 必要である。

利益相反 本研究において開示すべき利益相反はない.

\section{引用文献}

1) Taylor D: Physical activity is medicine for older adults. Postgrad Med J, 2014, 90: 26-32.

2) 南方良章 : 身体活動性の評価法. 日本呼吸器学会誌, 2015, 4: 8-14.

3) Adachi T, Kono Y, Iwatsu K, et al.: Duration of moderate to vigorous daily activity is negatively associated with slow walking speed independently from step counts in elderly women aged 75 years or over: a cross-sectional study. Arch Gerontol Geriatr, 2018, 74: 94-99.

4) Ainsworth BE, Haskell WL, Whitt MC, et al.: Compendium of physical activities: an update of activity codes and MET intensities. Med Sci Sports Exerc, 2000, 32: S498-S504.

5) Izawa KP, Shibata A, Ishii K, et al.: Associations of low-intensity light physical activity with physical performance in community-dwelling elderly Japanese: a cross-sectional study. PLoS One, 2017, 12: e0178654.

6) 天笠志保, 菊池宏幸, 福島教照・他：地域在住高齢者にお ける社会参加の類型と座位行動·身体活動パターンとの関連. 運動疫学研究, 2018, 20: 5-15.

7) Adachi T, Kamiya K, Kono Y, et al.: Predicting the future need of walking device or assistance by moderate to vigorous physical activity: a 2-year prospective study of women aged 75 years and above. BioMed Res Int, 2018, 2018: 1340479.

8) World Health Organization: Global recommendations on physical activity for health. World Health Organization, Geneva, 2010, pp29-33

9) 厚生労働省 : 介護保険事業状況報告. https://www.mhlw. go.jp/toukei/list/84-1.html (閲覧日 2020年7月 29日).

10) 厚生労働省：要介護認定. https://www.mhlw.go.jp/stf/ seisakunitsuite/bunya/hukushi_kaigo/kaigo_koureisha/nintei/ index.html (閲覽日 2021 年 4 月 3 日).

11) 菱井修平 : 在宅要介護高齢者を対象とした日常身体活動量 と身体組成および運動器機能との関連性一デイケアセンター Hに打㳊調査報告一. 川崎医療福祉学会誌, 2017, 26: 298-303.

12) 安藤 卓, 樋口由美, 今岡真和・他：軽度要介護者の通所 介護サービス利用日と非利用日の日内歩数推移に関する予 備的研究. 総合リハビリテーション, 2018, 46: 359-364.

13) Hasegawa J, Suzuki H, Yamauchi T: Impact of season on the association between muscle strength/volume and physical activity among community-dwelling elderly people living in snowy-cold regions. J Physiol Anthropol, 2018, 37: 25.

14) Ohkawara K, Oshima Y, Hikihara Y, et al.: Real-time estimation of daily physical activity intensity by a triaxial accelerometer and a gravity-removal classification algorithm. Br J Nutr, 
2011, 105: 1681-1691.

15) Yesavage JA: Geriatric depression scale. Psychopharmacol Bull, 1988, 24: 709-711.

16) Baker PS, Bodner EV, Allman RM: Measuring life-space mobility in community-dwelling older adults. J Am Geriatr Soc, 2003, 51: 1610-1614.

17) Carroll SL, Greig CA, Lewis SJ, et al.: The use of pedometers in stroke survivors: are they feasible and how well do they detect steps? Arch Phys Med Rehabil, 2012, 93: 466-470.

18) 厚生労働省: 平成 30 年国民健康 - 栄養調査報告. https:// www.mhlw.go.jp/stf/seisakunitsuite/bunya/kenkou_iryou/ kenkou/eiyou/h30-houkoku_00001.html（閲覧日 2020年 8 月 19日)。

19) 後藤和也, 山本達郎, 柏崎ももこ・他: 介護度の異なる要 支援高齢者に打ける歩数の縦断的变化とその特徵. 理学療 法科学, 2018, 33: 623-629.

20) Franco MR, Tong A, Howard K, et al.: Older people's perspectives on participation in physical activity: a systematic review and thematic synthesis of qualitative literature. Br J Sports Med, 2015, 49: 1268-1276.

21) 村田 伸, 大田尾浩, 村田 潤 - 他：虚弱高齢者に抢ける Timed Up and Go Test, 歩行速度, 下肢機能との関連. 理 学療法科学, 2010, 25: 513-516.

22) 村田伸, 矢田博幸, 岡村祐一・他：抑うつ傾向にある
高齢者の歩行の特徵. ヘルスプロモーション理学療法研究, 2017, 7: 127-131.

23) 池田 望, 村田 伸, 大田尾浩 - 他：地域在住女性高齢者 の握力と身体機能との関係. 理学療法科学, 2011, 26: 255258.

24) Shephard RJ, Park H, Park S, et al.: Objectively measured physical activity and progressive loss of lean tissue in older Japanese adults: longitudinal data from the Nakanojo study. J Am Geriatr Soc, 2013, 61: 1887-1893.

25) Ferris LT, Williams JS, Shen CL: The effect of acute exercise on serum brain-derived neurotrophic factor levels and cognitive function. Med Sci Sports Exerc, 2007, 39: 728-734.

26) Frith E, Loprinzi PD: Accelerometer-assessed light-intensity physical activity and mortality among those with mobility limitations. Disabil Health J, 2018, 11: 298-300.

27) Amagasa $S$, Machida M, Fukushima N, et al.: Is objectively measured light-intensity physical activity associated with health outcomes after adjustment for moderate-to-vigorous physical activity in adults? A systematic review. Int J Behav Nutr Phys Act, 2018, 15: 65.

28）e-ヘルスネット（厚生労働省）：健康づくりのための身体活 動基準 2013. https://www.e-healthnet.mhlw.go.jp/information/exercise/s-01-001.html (閲覧日 2020年7月 29 日). 